\title{
Versi Teori Difusi Inovasi untuk Menafsir Mimpi Kaum Marhaen di Universitas Negeri Padang
}

\author{
ALIM HARUN PAMUNGKAS \\ Dosen Jurusan Pendidikan Luar Sekolah Fakultas Ilmu Pendidikan \\ Universitas Negeri Padang \\ Jalan Prof. Dr. Hamka, Kampus UNP Air Tawar, \\ Kota Padang (25131), Sumatera Barat. \\ Telepon +62-822-3029-4393. \\ Surel alimharun@fip.unp.ac.id, pamungkasd527@gmail.com
}

T

ujuan saya menulis bahan ini adalah sebagai pengantar diskusi kita tentang mengembangkan organisasi ini di Universitas Negeri Padang. Sebagai langkah awal dari pencarian benang merah dari beragamnya ide kita yang berserakan. Tulisan ini dipandu oleh cara pandang teori difusi inovasi dari Gabriel Tarde di awal 1900-an yang selanjutnya dikembangkan oleh Everett M. Roger pada 1960-an.

Cara pandang difusi inovasi digunakan untuk melihat sejauh mana individu atau suatu kelompok dalam mengadopsi sebuah inovasi. Inovasi yang dimaksud adalah gagasan, pengetahuan, dan teknologi.

Dalam konteks organisasi kita (GMNI di UNP) berarti sejauh mana gagasan nasionalisme diadopsi oleh mahasiswa. Atau sejauh mana mahasiswa di UNP mengenal GMNI dari aspek keorganisasian, aktivitas, dan perannya pada organisasi kemahasiswaan di UNP. Bagian ini merupakan pembatasan yang diusulkan melalui tulisan ini.

\section{Praksis Karakteristik Inovasi}

Empat ciri inovasi yang dapat diadopsi dari Rogers adalah (1) relative advantage (keuntungan relatif), (2) compatibility (kesesuaian), (3) complexity (kerumitan), (4) triablity (siap uji).

Pertama, relative advantage (keuntungan relatif). Ciri ini dapat didekati dari elaborasi menggunakan hasil baca tentang teori dramaturgi. Ciri ini terkait dengan seberapa besar atau sedalam apa mahasiswa UNP merasakan efek nyata (kepuasan) dari keberadaan GMNI di UNP.
Semakin besar mahasiswa UNP merasakan efek nyata dari gagasan, program, dan kiprah kader GMNI di UNP, maka semakin cepat pula GMNI dikenal di UNP.

Kedua, compatibility (kesesuaian). Ciri ini dapat didekati dari elaborasi dari hasil baca tentang teori fenomenologi. Ciri ini berhubungan dengan sesuai atau tidaknya pola organisasi GMNI bagi kebutuhan pengembangan organisasi kemahasiswaan di UNP. Lebih dalam, adalah menilik kesesuaian kiprah kader GMNI dalam keterlibatan di dalam kegiatan kemahasiswaan di berbagai tingkatan.

Ketiga, complexity (kerumitan). Pemahaan tentang ciri ini dapat didekati menggunakan teori semiotka komunikasi. Ciri ini berkaitan dengan kerumitan yang mungkin akan dihadapi mahasiswa di UNP untuk memahami gagasan yang diusung oleh GMNI, seperti nasionalisme, sosialisme Indonesia (marhaenisme).

Keempat, triability (siap uji). Ciri ini dapat didekati melalui teori spiral of silence (spiral keheningan). Ciri ini menuntut situasi yang lebih rumit. Ciri ini menuntut semua kader GMNI UNP untuk dapat mengejawantahkan pemahamannya tentang ideologi dan pola gerakan GMNI dalam kehidupan keorganisasian di UNP. Sebuah ide yang ditawarkan oleh GMNI tentang suksesi kepemimpinan Ormawa misalnya haruslah bersifat siap uji dan mampu terap. Keberhasilan atau kelaikan dari hasil uji tersebut akan memperkuat pengetahuan khalayak UNP tentang kelebihan dan kekurangan dari gagasan besar yang diusung oleh GMNI. 


\section{Praksis Elemen Difusi Inovasi}

Empat elemen lengkap dari teori difusi inovasi adalah inovasi, saluran komunikasi, jangka waktu, dan sistem sosial.

Pertama, inovasi. Dalam konteks tulisan ini diartikan sebagai gagasan atau tindakan yang dicetuskan oleh GMNI UNP untuk lahirnya suatu kreasi baru di UNP. Kreasi bisa berwujud ide diskusi atau seminar yang bernas, pola organisasi dan tata kerja baru, atau bentuk kegiatan masal yang belum pernah diselenggarakan di UNP. Targetnya adalah keberterimaan khalayak UNP bahwa hal tersebut benar-benar baru.

Kedua, saluran komunikasi. Inovasi yang dicetuskan oleh GMNI UNP hanya dapat diadopsi oleh seorang mahasiswa atau khalayak UNP jika dikomunikasikan. GMNI UNP wajib untuk membangun jaringan dengan berbagai unit organisasi kemahasiswaan sebagai saluran komunikasi dalam realisasi gagasan ke-GMNI-an. Semakin tinggi target yang hendak dicapai, maka semakin tinggi pula level organisasi kemahasiswaan yang harus diakses oleh seluruh kader GMNI.

Ketiga, jangka waktu. Jangka waktu perlu ditetapkan. Jangka waktu ini adalah seberapa lama sejak suatu gagasan ke-GMNI-an mulai dikomunikasikan sampai kepada keputusan khalayak UNP untuk mengadopsi ke-GMNI-an.

Keempat, sistem sosial. Elemen ini dapat didekati dengan teori agenda setting. Elemen sistem sosial ini adalah organisasi kemahasiswaan UNP. Antara satu unit dengan unit lainnya dalam sistem organisasi kemahasiswaan di UNP memiliki perbedaan secara fungsional, namun terikat atas tujuan bersama yaitu majunya UNP. Artinya, target inovasi GMNI UNP adalah keberterimaan khalayak UNP.

\section{Praksis Tahapan Pengambilan Keputusan Inovasi}

Tahapan pengambilan keputusan inovasi terdiri dari (1) tahapan pengetahuan (knowledge), (2) tahapan persuasi (persuasion), (3) keputusan (decisions), (4) implementasi (implementation), dan (5) konfirmasi (confirmation).

Pertama, tahap munculnya pengetahuan (knowledge). Tahapan ini dapat didekati dengan kajian tentang komunikasi non verbal. Pada saat seorang mahasiswa atau khalayak UNP memahami bahwa inovasi ke-GMNI-an tersebut bernilai guna baginya, maka akan lebih mudah inovasi tersebut diadopsi. Oleh karena itu, suatu inovasi yang (dikomunikasikan) ditawarkan GMNI UNP adalah agar seorang mahasiswa atau khalayak UNP mengenali dan memahami manfaat inovasi yang ditawarkan.

Kedua, tahap persuasi (persuasion). Tahapan ini dapat didekati dengan memperdalam kajian tentang teori komunikasi massa. Pada tahapan ini seorang mahasiswa atau khalayak UNP mulai menunjukan sikap (baik atau buruk) terhadap inovasi yang ditawarkan oleh GMNI UNP. Ketiga, tahap keputusan (decisions). Tahapan ini bisa lebih jelas dikenali dengan kajiankajian yang berhubungan bahasa sebagai alat komunikasi. Tahapan ini seorang mahasiswa atau khalayak UNP telah sampai kepada tahapan pengambilan keputusan inovasi (diterima atau ditolak) yang ditawarkan GMNI UNP.

Keempat, tahapan implementasi (implementation). Tahap ini adalah tahap pada saat seorang mahasiswa atau khalayak UNP memutuskan untuk mengadopsi inovasi yang ditawarkan GMNI UNP. Jika tawaran inovasi diterapkan dalam salah satu aspek (misal organisasi kemahasiswaan UNP), maka seorang mahasiswa atau khalayak UNP telah dapat disebut sebagai adopter inovasi.

Kelima, tahapan konfirmasi (confirmation). Tahapan ini adalah tahap dimana seorang mahasiswa atau khalayak UNP telah sampai pada tahap mencari penguatan atas keputusannya untuk menolak mau pun menerima inovasi yang ditawarkan GMNI UNP untuk diadopsi.

\section{REFERENSI}

Everett M. Rogers. 1983. Diffusion of Innovations. London: The Free Press. 